MICROZONING REPORT

\title{
MICROZONING FOR EARTHQUAKE EFFECTS IN THE WELLINGTON CITY AREA
}

\author{
R. D. Adains*
}

A report with the above title is now being prepared for publication by the Department of Scientific and Industrial Research. The work embodied in the report was carried out by representatives of four divisions of D.S.I.R., who have been collaborating as a Microzoning Committee since 1968. A smaller report on microzoning in the Pauatahanui area was issued in 1970, but the wellington study is the first in a major urban area to have been undertaken in New Zealand. It is hoped to extend this type of work to other parts of New Zealand as time. permits.

Details of the Wellington Microzoning Report were presented at a meeting of the Geology section of the Wellington Branch of the Royal Society of New Zealand on 6th July 1972. The final microzone map was on display, together with the detailed maps of geology, soil type, and geophysical information that were taken into account in its compilation.

In opening the presentation, Mr. T. L. Grant-Taylor, New Zeal and Geological Survey, D.S.I.R., emphasised the interdisciplinary nature of the work, and said that to his knowledge the only places where similar work had been undertaken were in small areas of Japan and the Soviet Union. He stressed that these microzoning results should be used as a guide to planning only, and should not replace detailed site investigations for particular projects or buildings.

Dr. R. D. Adams, Geophysics Division, D.S.I.R., referred briefly to wellington's earthquake history, and pointed out that this study was undertaken in wellington not because wellington was more prone to earthquakes than other centres in New Zealand, but because its diversity of soil types made it a good testing ground for developing techniques, and because of its proximity to the various D.S.I.R. offices involved. He also presented the gravitational and microseismic noise measurements used in the compilation of the microzone map. Decreases in the value of gravity, and increases in the levels of microseismic noise both give indications of thickening of less dense overburden that could cause seismic wave amplification in the ground. These two independent techniques gave results in excellent agreement.

The next speaker, Mr. W. R. Stephenson, Physics and Engineering Laboratory, D.S.I.R., summarised theoretical studies of wave amplification and resonance in superficial layers, and pointed out that effects on structures could be aggravated when the resonant frequency of the ground coincided with that of the

* Seismological observatory, Wellington. structure. Large stiff structures could also be affected by relative displacement and rotation of the underlying soil during the passage of earthquake waves. Physics and Engineering Laboratory has installed at nine points around Wellington, strong-motion recorders that will be able to determine directly any differences in ground response due to subsoil effects during future strong earthquakes in wellington.

Dr. R. D. Northey, Soil Bureau, D.S.I.R., explained that pedologists could map soils in much greater detail than was necessary for engineering classification. For simplicity, he classified the soils of the Wellington area into six main types, which were mapped for the area. These ranged from nan-made fill and sandy soils to hard rock. Dr. Northey also presented information about the distribution of damage claims resulting from the magnitude $5 \frac{1}{2}$ earthquake of 1 November, 1968. In areas of poorer soil, including fill, up to 120 claims per 1000 houses were received by the Earthquake and War Damage Commission. There was a lessening of the number of claims with increasing competency of soil type until a figure of about 13 claims per 1000 houses was reached where the greywacke basement outcropped.

The geology of the area was discussed by Mr. Grant-Taylor, who assembled all the previous information into an isopach map showing estimated thickness to basement rock, and from this derived the final microzone map. The area was classified into three types of zone, according to soil type, and a further zone in which there was risk of topographic failure.

Zone 1 comprises areas where the basement rock is at the surface or within $10 \mathrm{~m}$ of it. This zone includes most hill suburbs of the city, but excludes the area of land in the zone of crushed basement rock near the wellington Fault.

Zone 2 includes compact sediment of thickness greater than $10 \mathrm{~m}$, completely weathered basement rock, and fault gouge. It includes the low relief areas of Karori, Thorndon, Newtown, Berhampore and parts of Te Aro.

Zone 3 comprises areas of highly porous sediments, and extends into reclaimed areas. It includes the reclaimed areas of Thorndon the central city, low-lying parts of Kilbirnie, Rongotai, Miramar and Seatoun. In general, these areas are where geophysical and geological evidence indicates significant thickness of low-density sediment.

The Topographic Failure zone covers those areas where the slope is such that earthquake-generated landslides could occur. This zone is 
The map also traces the positions of active faults. The Wellington Fault, extending along Tinakori Road, and to the south-east of Karori, must be regarded as being liable to move in the ruture. Its main feature from the microzoning point of .view, however, is the zone of crushed rock along the fault, which would be expected to behave like the compacted alluvium of Zone 2. The Lambton Fault, extending through the central city, is thought to move so infrequently as to have little significance for planning.

It is expected that during any particular earthquake the amplification in vibration between successive zones will correspond roughly to one step of the Modified Mercalli Scale. Thus, Zone 3 may expect intensities of up to two MM steps higher than those in zone 1, but variations will occur from earthquake to earthquake.

After explaining the details of the microzone map, Mr. Grant-Taylor showed a detailed plan of minor building damage that occurred in central Wellington during the earthquake of 1 November 1968. There were bands of differing type and extent of damage in the part of the area lying in zone 3, showing some correlation with the thickness of overburden, as given on the isopach map. It is obvious that smallerscale patterns of intensity will exist in the main zones, and Mr. Grant-Taylor believes that these may repeat from earthquake to earthquake.

The final speaker was Mr. O. A. Glogau, Chief Structural Engineer, Ministry of Works, who has acted in an advisory capacity on the Microzoning Committee. With the help of diagrams, Mr. Glogau demonstrated the importance of the soil effect on the design of buildings. He thought that considerable uncertainty existed at present with regard to changes in spectral density and amplification of earthquake motions due to soil effects. Strong earthquake motion from distant earthquakes was known to be greatly amplified and modified by soft soils, but much less appeared to be known about the soil modification of earthquake motion from large near earthquakes. A mathematical treatment of the problem was possible, as shown by the work of seed, Taylor, and others, but more instrumental records were required to check these results. The value of the present research was that it outlined two zones of soils in which the modifications of the earthquake motion compared with that on bedrock would differ significantly. Very broad modifications to design spectra could be made now, and would result in more realistic designs.

After questions on details of the map from the floor, Prof. F. F. Evison, Institute of Geophysics, Victoria University of Wellington, moved a vote of thanks to the speakers, and through them to the members of the Microzoning Committee who had carried out the investigations in the various disciplines. 